\title{
Relationship between Work-Life Balance, Religiosity and Employee Engagement: A Proposed Moderated Mediation Model
}

\author{
Hieu Minh VU ${ }^{1}$
}

Received: July 18, 2020 Revised: August 23, 2020 Accepted: August 28, 2020

\begin{abstract}
Human resource is considered as an important resource that enables organizations to achieve competitive advantage. As such, it is important to have engaged employees to drive the strategic objectives of the organization. The study focuses on variables that can promote employee engagement. Work-life balance and employee engagement have received attention in both academia and practice. Engaged employees are crucial in the achievement of the strategic objectives of organizations. Besides, the role of religious orientation in life and work has been gaining attention from management scholars. The paper attempts to fill the research gap by developing a conceptual model and propositions for empirical testing. Specifically, the study proposes that work-life balance is expected to act as a mediator in the relationship between religiosity and employee engagement. Furthermore, religiosity is included as a moderator since religious belief can strengthen the positive relationship between work-life balance and employee engagement. A systematic literature review was carried out. A framework and propositions for future studies have been developed. The proposed framework provides direction for scholars to empirically test the indirect relationship between work-life balance, religiosity and employee engagement. Empirical testing of the framework could provide insights into how work-life balance and religiosity promote employee engagement.
\end{abstract}

Keywords: Employee Engagement, Extrinsic, Intrinsic, Religiosity, Work-Life Balance

JEL Classification Code: J10, M10, L10

\section{Introduction}

The last few years have seen employees struggling to effectively manage competing demands between work and private lives. Globalization, changing technology, dynamic workplace, and demographic changes (Kinnunen et al., 2014; Beauregard \& Henry, 2009; Gregory \& Milner, 2009) and workforce diversity (Dulk \& Groeneveld, 2012) placed equal importance on work and private lives. Worklife balance connotes the process in which workers try to combine paid jobs with family responsibilities to achieve a "balance" (Crompton \& Lyonette, 2006). To achieve this balance, employees must cope with pressures such as job

${ }^{1}$ First Author and Corresponding Author. Faculty of Business Administration, Van Lang University, Vietnam [Postal Address: 45 Nguyen Khac Nhu, Co Giang Ward, District 1, Ho Chi Minh City, 700000, Vietnam] Email: Vuminhhieu@vanlanguni.edu.vn

(c) Copyright: The Author(s)

This is an Open Access article distributed under the terms of the Creative Commons Attribution Non-Commercial License (https://creativecommons.org/licenses/by-nc/4.0/) which permits unrestricted non-commercial use, distribution, and reproduction in any medium, provided the original work is properly cited. requirements, role expectations, group and organizational norms (Crompton \& Lyonette, 2006). Extant literature suggests that work-life balance focuses on individual outcomes such as employees' behaviors, attitudes, satisfaction, physical and psychological health, well-being, and organizational effectiveness (Whittington et al., 2011; Eby et al., 2005), and organizational outcomes such as organizational commitment, individual performance, and reduced turnover intentions (Forsyth \& Polzer-Debruyne, 2007; Bloom \& van Reenen, 2006). A mismatch between work and family responsibilities could foster absenteeism, dissatisfaction, and low productivity (Edwards \& Rothbard, 2000).

Although work-life balance has received attention from scholars and practitioners, yet there is still more to understand (Beauregard \& Henry, 2009), especially the indirect role of work-life balance in the relationship between religiosity and employee engagement. It has been argued that religion shapes people's philosophy and behavior in life and work (Gundolf \& Filser, 2013). Some studies have shown that religiosity positively affects various human resources and organizational outcomes (Osman-Gani et al. 
2013; Kutcher et al. 2010; Branine \& Pollard, 2010; Ali et al. 2000; Hitchen, 2014) and employee engagement (e.g, Tennakoon \& Lasanthika, 2018). Yet, little is known about how religiosity indirectly influences work-life balance and employee engagement. It is interesting to examine this relationship since the mechanisms through which worklife balance (Beauregard \& Henry, 2009) and religiosity affects employee engagement are unclear and have been fully established. Employee engagement is an important component of high-performance work practices that fosters organizations survival (Schaufeli, 2013).

This study responds to call by scholars (e.g., Tennakoon \& Lasanthika, 2018; Nwachukwu et al., 2017) to incorporate othervariables thatmight have a directand indirectrelationship with employee engagement. Therefore, the present paper attempts to fill this gap by developing a conceptual model and propositions for empirical testing. Specifically, the study proposes that work-life balance is expected to act as a mediator in the relationship between religiosity and employee engagement. Furthermore, religiosity is included as a moderator since religion belief can strengthen the positive relationship between work-life balance and employee engagement. The study objective is achieved by reviewing and discussing some central contributions to the literature on work-life balance, religiosity and employee engagement. This paper is arranged as follows. In the following section, this paper presents an overview of the review of theoretical underpinning and concepts of work-life balance, religiosity and employee engagement. Followed by the methodology used in this study. Finally, conclusions and limitations and suggestions for future research are proposed.

\section{Literature Review}

\subsection{Work-Life Balance and Employee Engagement}

Scholars have examined the relationship between worklife or work-family literature for several years. Karthik (2013) notes that work-life is a fit between a person's time at the workplace and time outside the workplace (family life, friend life). Armstrong (2012) asserts that work-life balance focuses on how employees balance office work with family responsibilities. In terms of the definition of work-life balance, Frone's one is mostly used: "a shortage of conflict or interference between work and family/ life roles" (Frone, 2003). This is also agreed by Mustapa et al. (2018). Furthermore, many studies emphasize the absence of conflict between work and personal life as a component of work-life balance. Another component of work-life balance is work-life enrichment or facilitation (Mustapa et al., 2018).

Work-life balance promotes a positive environment for personal and for an individual (Beauregard \& Henry, 2009).
Myilswamy and Gayatri (2014) assert that engagement has a significant influence on workforce productivity, employee retention, customer loyalty and profitability. It can be argued that firms that promote work-life balance experience increased employee engagement and better productivity. Susi and Jawaharrani (2011) find that firms that are more aware of employee individual needs can design and reinforce policies and work-life balance practices that foster employee engagement. Richman et al. (2008) submit that supportive work-life policy and perceived flexibility promote employee engagement.

Similarly, Sonnentag (2003) concludes that recovery, which can be perceived as a dimension of work-life balance, foster employees' work engagement. Recovered employees are more dedicated to and fully concentrate on their work (Sonnentag, 2003). On the other hand, Schieman and Young (2013) report that work home conflict due to employees answering e-mails and phone out of office hours and weekend work impact negatively on employee engagement levels. Matthews et al. (2014) find that work-family conflict has a negative influence on employee wellbeing.

In addition, Sopiah et al. (2020) find and confirm that nurses' work engagement has a moderating role between talent management and work engagement for performance and the work-life balance and women career advancement are crucial to remain Malaysia females in their employment and motivate them to pursue promotion to a higher position. This is proved that there is the positive relationship between work-life balance and career advancement (Mustapa, Noor \& Mutalib, 2018). This issue has been documented in the study by Lyness and Judiesch $(2008,2014)$. Besides, Nguyen et al. (2019) depict that job crafting impacts positively on work engagement, which leads to individual work performance enhancement.

\subsection{Religiosity and Employee Engagement}

Religiosity is an orientation, a behavioral set and a lifestyle (Sedikides, 2010), which makes people strive for high standards and uphold their emotional well-being (Koole et al. 2010). As defined by Saleh et al. (2020), "religiosity means the state, understanding, and measurement of one's obedience in believing in a religion that is manifested in the experience of values, rules, obligations to encourage someone to behave and act following the teachings of the religion they hold in everyday life". Religion is connected to business and explains a set of behaviors that shows the worth of one's faith (Park \& Smith, 2000). Religiosity is the faith that a person has in God (McDaniel \& Burnett, 1990) and is strongly linked to morality (Geyer \& Baumeister, 2005).

According to Bloom (2012), religion solves the problem by connecting communities of people and promoting cooperation and group feelings. Arguably, religiosity can 
foster work engagement and employee performance at work. Ali et al. (2000) opine that human resource issues in organizations have their foundations in religion. Indeed, the role of religion in shaping people's philosophy and work behavior has been gaining attention from management scholars. Studies have shown that religiosity influence human resources and organizational outcomes (Bakar et al., 2016).

Empirically, Tennakoon and Lasanthika (2018) examine the relationship between religiosity and employee engagement in Sri Lankan institutions. The study has employed a quantitative and cross-sectional study using a 10 items-three component measurement and Utrecht Work Engagement Scale (UWES) with nine items to measure religiosity and engagement respectively and they conclude that a strong and positive association exists between religiosity and employee engagement. This result by Tennakoon and Lasanthika (2018) seems to be consistence with the study result by Saleh et al. (2020) showing that the direct combined effect of reward and religiosity has a positive and significant impact on the engagement. On the other aspect, in the role of moderator, religiosity does not impact on reward and commitment (Saleh et al., 2020).

Work-family border theory suggests that work and family influence each other and both can be managed to achieve desired work-life balance. The social exchange theory suggests that employees will put in their best when they are cared for and supported by their organization. The JD-R model suggests that job demands or job resources influence employees' work attitudes. Intrinsic religiosity fosters ethical judgments while extrinsic religiosity has only a very limited impact or no impact at all. Social support theory can be used to explain the support employees get in terms of robust work-life balance practices and its impact on religiosity and employee engagement.

\section{Methodology}

A systematic literature review was conducted to obtain relevant articles within the work-life balance, religiosity and employee engagement domain. Systematic literature review minimizes bias through a comprehensive literature search (Tranfield et al., 2003). The author used the keywords such as work-life balance, religiosity and employee engagement literature to search for articles. The review focused on both qualitative and quantitative studies from 1976 to 2020. In total, 54 articles from EBSCO host, Google Scholar, Scopus and Web of Science databases were reviewed.

\section{Results and Findings}

The author reasons that religiosity positively influences employee engagement through work-life balance. This suggests that work-life balance mediates the relationship between religiosity and employee engagement. On the other hand, the relationship between work-life balance and employee engagement may be strengthened or constrained by the religious orientation of an individual. This means that religiosity moderates the effect of work-life balance on employee engagement. The study will assist organizations to ascertain the importance of work balance life and religiosity in promoting employee engagement.

Specifically, the organization will know whether religiosity foster employee engagement and whether religiosity strengthens the impact of work balance life on employee engagement or not. Three dimensions of work-life balance should be considered: work-family conflict (WFC), family satisfaction (FS), and work satisfaction (WS). Workfamily conflict (WFC) connotes the extent to which the demands of one role make it hard to perform another role (Greenhaus \& Beutell, 1985). Family satisfaction focuses on the satisfaction that the family members get from all activities and communication experiences with the family (Mehmet, 2020).

Work satisfaction is the degree to which an employee is contented with the rewards he or she received from work, particularly in terms of intrinsic motivation (Statt, 2004). Concerning religiosity, the study draws from Allport and Ross' (1967) extrinsic and intrinsic religiosity. Extrinsically-motivated individuals use religion for their

Table 1: Theories underpinning the concept of work-life balance, religiosity, and employee engagement

\begin{tabular}{|l|l|l|}
\hline Variables & Theories & Literature \\
\hline Work-Life Balance & $\begin{array}{l}\text { Work-Family Border Theory, } \\
\text { Social Exchange theory, Job } \\
\text { Demands-Resources (JD-R) } \\
\text { model }\end{array}$ & $\begin{array}{l}\text { Clark (2001); Demerouti, Bakker, Nachreiner and Schaufeli } \\
\text { (2001); Bakker and Demerouti (2007); Eisenberger, } \\
\text { Stinglhamber, Vandenberghe, Sucharski and Rhoades } \\
\text { (2002); de Jonge, Demerouti and Dormann (2014) }\end{array}$ \\
\hline Religiosity & $\begin{array}{l}\text { Extrinsic religiosity, intrinsic } \\
\text { religiosity }\end{array}$ & $\begin{array}{l}\text { Allport and Ross (1967); Patwardhan et al. (2012; Vitell et } \\
\text { al. (2005); Vitell (2009); Vitell et al. (2009) }\end{array}$ \\
\hline Employee Engagement & $\begin{array}{l}\text { Social Support Theory, Social } \\
\text { Exchange theory }\end{array}$ & $\begin{array}{l}\text { Cohen and Wills (1985); Eisenberger et al (1986); Cobb, } \\
1976\end{array}$ \\
\hline
\end{tabular}


interest and intrinsically-motivated people live according to religious values (Nwachukwu et al., 2017; Allport \& Ross, 1967). Soane et al. (2012) conceptualize employee engagement as consisting of intellectual, social, affective dimensions. The ISA engagement scale should be used to access employee engagement. The ISA engagement scale is appropriate to measure employee reactions to their work environment and to monitor engagement. In light of these, the hypotheses of the research are presented below:

H1. Work-life balance mediates the relationship between religiosity and employee engagement

H1a. Work-family conflicts mediate the relationship between religiosity and employee engagement

H1b. Family satisfaction conflicts mediate the relationship between religiosity and employee engagement

H1c. Work satisfaction conflicts mediate the relationship between religiosity and employee engagement

H2. Religiosity moderates the impact of work-life balance on employee engagement

H2a. Extrinsic religiosity moderates the impact of worklife balance on employee engagement

$\boldsymbol{H} \mathbf{2 b}$. Intrinsic religiosity moderates the impact of worklife balance on employee engagement

Proposed Conceptual Framework: Grounded in the theoretical framework, a conceptual research model has been developed based on the following variables. Dependent variable: employee engagement (intellectual, social and affective) depends on these independent variables. Mediator variables: work-life balance (work-family conflicts, family satisfaction and work satisfaction). Moderator variables: religiosity (extrinsic and intrinsic) (see Figure 1).

Where:

WLB- work-life balance, WFC- work-family conflicts, FS- family satisfaction, WS- work satisfaction, RSreligiosity, IR- intrinsic religiosity, ER- intrinsic religiosity, EE- employee engagement, IE- intellectual engagement, SEsocial engagement, AE- affective engagement.

Detail descriptions of all variables and dimensions in the above conceptual framework:

Work-family conflicts include: i) the demand of my work interfere with my home and family life; ii) the amount of time my job takes makes it difficult to fulfil my family responsibilities; iii) things I want to do at home do not get done because of the demands my job puts on me; iv) my job produces strain that makes it difficult to fulfil family duties; v) due to work-related duties, I have to make changes to my plans for family activities.

Family satisfaction includes: (i) the conditions of my family- life are excellent; (ii) in most ways my family-life is close to my deal; (iii) I am satisfied with my family-life; (iv) so far I have got the important things I want in my family-life; (v) due to work related duties, I have to make changes to my plans for family activities.

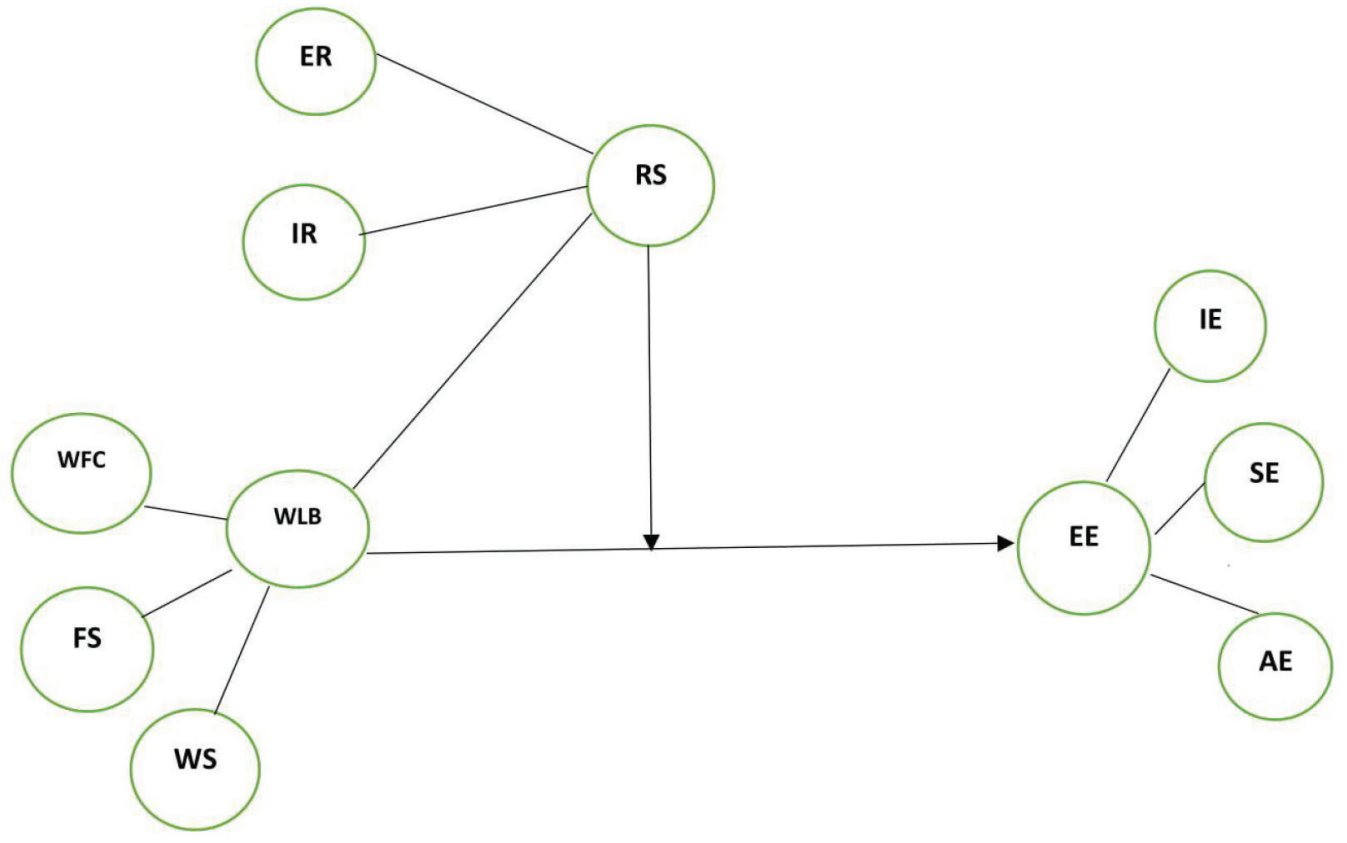

Figure 1: Proposed model 
Work satisfaction includes: i) generally speaking, I am very happy with my work; ii) I frequently think of leaving this job; iii) I am generally satisfied with the kind of work $i$ do in my job.

Religiosity-extrinsic includes: i) the place of worship is most important place to formulate good social relationships; ii) the purpose of prayer is to secure a happy and peaceful life; iii) what religion offers me most is comfort when sorrows and misfortune strike; (iv) it doesn't matter so much what I believe so long as I lead a moral life; (v) although I am a religious person, I refuse to let religious considerations influence my everyday affairs; (vi) I pray chiefly because I have been taught to pray; (vii) a primary reason for my interest in religion is that it is a congenial social activity; (viii) occasionally I find it necessary to compromise my religious beliefs in order to protect my social and economic well-being; (ix) the primary purpose of prayer is to gain relief and protection; (x) although I believe in my religion, I feel there are many more important things in my life; (xi) religion helps to keep my life balanced and steady in exactly the same way as my citizenship, friendships, and other memberships do; (xii) one reason for my being a member of religious organization is that such membership helps to establish a person in the community.

Religiosity-intrinsic includes: i) I try hard to carry my religion over into all my other dealings in life; ii) quite often I have been keenly aware of the presence of God or the Divine Being; iii) the prayers I say when I am alone carry as much meaning and personal emotion as those said by me during services; (iv) it is important to me to spend time in private religious thought and meditation; (v) my religious beliefs are what really lie behind my whole approach to life; (vi) religion is especially important to me because it answers many questions about the meaning of life; (vii) I read literature about faith; (viii) if I were to join a religious group, I would prefer to join (1) a study group, or (2) a social fellowship; (ix) if not prevented by unavoidable circumstances, I attend religious meeting.

Employee engagement-intellectual includes: i) I focus hard on my work; ii) I concentrate on my work; iii) I pay a lot of attention to my work. Employee engagement-social includes: i) I share the same work values as my colleagues; ii) I share the same work goals as my colleagues; iii) I share the same work attitudes as my colleagues. Employee engagement-affective includes: i) I feel positive about my work; ii) I feel energetic in my work; iii) I am enthusiastic in my work.

A 5-point Likert scale ranging from 1 = strongly disagree to 5 =strongly agree should be used to obtain information from participants. SmartPLS Structural equation Modelling (SEM) should be used to test the mediation-moderation relationship in the proposed framework. Smart PLS software is relevant for prediction-oriented and exploratory study (Hair et al., 2016). Smart PLS is a robust tool for simultaneously analyzing multiple dependency relationships with higher statistical efficiency (Ringle \& Sarstedt, 2016).

\section{Conclusions}

\subsection{Conclusions}

Human resource is considered as an important resource that enables organization to achieve competitive advantage. As such, it is important to have engaged employees to drive the strategic objectives of the organization. The study focuses on variables that can promote employee engagement. The proposed framework identifies the different measures of work-life balance, religiosity and employee engagement. Considering the limitations and gaps in the literature, a model with its associated propositions was developed. It is focused on empirically testing the direct effect of work-life balance and religiosity on employee engagement. The proposed framework can be applied to similar situations in different contexts and countries. The empirical testing of this framework would enrich the literature on work-life balance and religiosity in terms of how these construct foster employee engagements. Arguably, work-life balance and religiosity are important to keep employees engaged with their organizations.

\subsection{Implications}

Based on the proposed model, this study attempts to create different measures of employee engagement where a few factors may be removed or added in the model for fostering its effectiveness. It will be interesting to understand whether the proposed framework depends on diverse contexts. Hence, an evaluation of the proposed model in different countries and firms may generate useful insights into how different factors foster employee engagement. Specifically, the proposed framework, could enrich our outstanding of how work-life balance and religiosity promote or hinders the level of employee engagement. This can help organizations to perform better. Furthermore, an empirical study could highlight whether the proposed framework will be beneficial for managers and executives or not.

\subsection{Limitations and Future Research Agenda}

The present paper only developed a framework and three main propositions for empirical testing. Further research should empirically test the model and variables conceptualized in this study. Scholars should examine the indirect relationship between work life balance, religiosity and employee engagement. Future empirical studies should support the proposed model in terms of significance, practicability, and capability. 


\section{References}

Ali, A. J., Gibbs, M. \& Camp, R. C. (2000). Human resource strategy: The ten commandments perspective. International Journal of sociology and Social Policy, 20(5/6),114-132.

Allport, G. W. \& Ross, J. M. (1967). Personal religious orientation and prejudice. Journal of Personality and Social Psychology $5,432-443$

Armstrong, M. (2012). Armstrong's Handbook of Human Resource Management Practice (12th ed.). London, UK: Kogan Page.

Bakar, R. A., Cooke, F. L \& Nuttawuth, M. (2016). Religiosity as a source of influence on work engagement: a study of the Malaysian Finance industry. The International Journal of Human Resource Management, 29(18), 2632-2658. https://doi. org/10.1080/09585192.2016.1254103

Bakker, A. B., \& Demerouti, E. (2007). The job demands-resources model: State of the art. Journal of Managerial Psychology, 22(3), 309-328.

Beauregard, T. A., \& Henry, L. C. (2009). Making the link between work-life balance practices and organizational performance. Human Resource Management Review, 19(1), 9-22.

Bloom, N., \& Van Reenen, J. (2006). Management practices, work-life balance, and productivity: A review of some recent evidence. Oxford Review of Economic Policy, 22(4), 457-482.

Bloom, P. (2012). Religion, morality, evolution. Annual Review of Psychology 63, 179-199.

Branine, M. \& Pollard, D. (2010). Human resource management with Islamic management principles. Personnel Review 39, 712-727.

Clark, S. (2001). Work/family border theory: a new theory of work/ family balance. Human Relations, 53(6), 747-770.

Cobb, S. (1976). Social support as a moderator of life stress. Psychosomitic Medicine, 3, 300-314.

Cohen, S., \& Wills, T. A. (1985). Stress, social support, and the buffering hypothesis. Psychological Bulletin, 98(2), 310-357.

Crompton, R., \& Lyonette, C. (2006). Work-life 'balance' in Europe. Acta Sociologica, 49(4), 379-393.

De Jonge, J., Demerouti, E., \& Dormann, C. (2014). Current theoretical perspectives in work psychology. In: M. C. W. Peeters, J. de Jonge, \& T. W. Taris (Eds.), An introduction to contemporary work psychology (pp. 89-113). Chichester, UK: John Wiley \& Sons.

Demerouti, E., Bakker, A. B., Nachreiner, F., \& Schaufeli, W. B. (2001). The job demands resources model of burnout. Journal of Applied Psychology, 86(3), 499-512.

Dulk, L., \& Groeneveld, S. (2012). Work life balance support in the public sector in Europe. Review of Public Personnel Administration, 33(4), 384-405.

Eby, L. T., Casper, W. J., Lockwood, A., Bordeaux, C., \& Brinley, A. (2005). Work and family research in IO/OB: Content analysis and review of the literature (1980-2002). Journal of Vocational Behavior, 66(1), 124-197.

Edwards, J. R., \& Rothbard, N. P. (2000). Mechanisms linking work and family: Clarifying the relationship between work and family constructs. Academy of Management Review, 25(1), 178-199.

Eisenberger, R., Huntington, R., Hutchison, S., \& Sowa, D. (1986). Perceived organizational support, Journal of Applied Psychology, 71(3), 500-507.

Eisenberger, R., Stinglhamber, F., Vandenberghe, C., Sucharski, I. L., \& Rhoades, L. (2002). Perceived supervisor support: Contributions to perceived organizational support and employee retention. Journal of Applied Psychology, 87(3), 565-573.

Forsyth, S., \& Polzer-Debruyne, A. (2007). Theal pay-offs for perceived work life balance support. Asia Pacific Journal of Human Resources, 45(1), 113-123.

Geyer, A. L., \& Baumeister, R. F. (2005). Religion, morality, and self-control. In: R. F. Paloutzian \& C. L. Park (Eds.), The handbook of religion and spirituality (pp. 412-432). New York, NY: The Guilford Press.

Greenhaus, J. H., \& Beutell, N. J. (1985). Sources of conflict between work and family roles. Academy of Management Review, 10(1), 76-88.

Gregory, A., \& Milner, S. (2009). Editorial: Work-life balance: A matter of choice? Gender, Work and Organization, 16(1), 1-13.

Gundolf, K., \& Filser, M. (2013). Management research and religion: A citation analysis. Journal of Business Ethics 112, 177-185.

Hair, J. F. Jr, Hult, G. T. M., Ringle, C., \& Sarstedt, M. (2016). A Primer on Partial Least Squares Structural Equation Modeling (PLS-SEM), New York, NY: Sage Publications.

Hitchen, J. M. (2014). Towards a theology of business for christians in a primal religious society in a globalising world. Melanesian Journal of Theology, 30, 74-104.

Karthik, R. (2013). A study on work-life balance in Chennai port trust, Chennai. Advances in Management. Psychology, 19(4), 429-459.

Kinnunen, U., Rantanen, J., Mauno, S., \& Peeters, M.C.W. (2014). Work-family interaction. In: M. C. W. Peeters, J. de Jonge, \& T. W. Taris (Eds.), An introduction to contemporary work psychology (pp. 267-289). Chichester, UK: John Wiley \& Sons.

Koole, S. L., McCullough, M. E., Kuhl, J., \& Roelofsma, P. H. (2010). Why religion's burdens are light: From religiosity to implicit self-regulation. Personality and Social Psychology Review, 14, 95-107.

Kutcher, E. J., Bragger, J. D., Rodriguez-Srednicki, O., \& Masco, J. L. (2010). The role of religiosity in stress, job attitudes, and organizational citizenship behavior. Journal of Business Ethics, 95, 319-337.

Matthews, R. A., Wayne, J. H., \& Ford, M. T. (2014). A workfamily conflict/subjective well-being process model: A test of 
competing theories of longitudinal effects. Journal of Applied Psychology, 99, 1173-1187.

McDaniel, S. W., \& Burnett, J. J. (1990). Consumer religiosity and retail store evaluative criteria. Journal of the Academy of Marketing Science, 18, 101-112.

Mehmet, A. Ç. (2020). The effects of family communication patterns on family satisfaction in family business. Global In: Applications of Multigenerational Management and Leadership in the Transcultural Era (pp. 35-40).

Mustapa, S. N., Noor, M. K., \& Mutalib, A. M. (2018). Why Can't We Have Both? A Discussion on Work-Life Balance and Women Career Advancement in Malaysia. Journal of Asian Finance, Economics and Business, 5(3), 103-112. http://doi. org/10.13106/jafeb.2018.vol5.no3.103

Myilswamy, \& Gayatri, R. (2014). A Study on Employee Engagement: Key to Organizational Success. International Journal of Innovative Science, Engineering and Technology, 1(6), 331-333.

Nguyen, H. M., Nguyen, C., Ngo, T. T., \& Nguyen, V. L. (2019). The Effects of Job Crafting on Work Engagement and Work Performance: A Study of Vietnamese Commercial Banks. Journal of Asian Finance, Economics and Business, 6(2), 189201. https://doi.org/10.13106/jafeb.2019.vol6.no2.189

Nwachukwu, C., Žufan, P., \& Chládková, H. (2016). Religiosity, HPWPs, and Employee engagement: a conceptual review. Paper presented at 20th European Scientific Conference of Doctoral Students. November 24, 2016, Brno, Czech Republic.

Osman-Gani, A. M., Hashim, J., \& Ismail, Y. (2013). Establishing linkages between religiosity and spirituality on employee performance. Employee Relations 35, 360-376.

Park, J. Z., \& Smith, C. (2000). To whom much has been given: Religious capital and community voluntarism among churchgoing Protestants. Journal for the Scientific Study of Religion, 38, 272-286.

Patwardhan, A. M., Keith, M. E., \& Vitell, S. J. (2012). Religiosity, attitude toward business, and ethical beliefs: Hispanic consumers in the United States. Journal of Business Ethics, $110,61-70$

Richman, A. L., Civian, J. T., Shannon, L. L., Hill, J. E., \& Brennan, R. T. (2008). The relationship of perceived flexibility, supportive work-life policies, and use of formal flexible arrangements and occasional flexibility to employee engagement and expected retention. Community, Work and Family, 11(2), 183-197.

Ringle, C. M., \& Sarstedt, M. (2016). Gain more insight from your PLS-SEM results: The importance-performance map analysis. Industrial Management \& Data Systems, 116(9), 1865-1886.

Saleh, C., Hayat, H., Sumartono, S., \& Pratiwi, N. R (2020). Moderating of Religiosity on Reward and Engagement: Empirical study in Indonesia Public Service. Journal of Asian
Finance, Economics and Business, 7(6), 287-296. https://doi. org/10.13106/jafeb.2020.vol7.no6.287

Schaufeli, W. B. (2013). What is engagement? In: C. Truss, K. Alfes, R. Delbridge, A. Shantz, \& E. Soane (Eds.), Employee Engagement in Theory and Practice. London, UK: Routledge.

Schieman, S., \& Young, M. C. (2013). Are communications about work outside regular working hours associated with work-to-family conflict, psychological distress and sleep problems? Work Stress, 27(3), 244-261.

Sedikides, C. (2010). Why does religiosity persist? Personality and Social Psychology Review, 14, 3-6.

Soane, E., Truss, C., Alfes, K., Shantz, A., Rees, C., \& Gatenby, M. (2012). Development and application of a new measure of employee engagement: the ISA Engagement Scale. Human Resource Development International, 15, 529 -547.

Sonnentag, S. (2003). Recovery, work engagement, and proactive behavior: a new look at the interface between nonwork and work. Journal of Applied Psychology, 88(3), 518-528.

Sopiah, S., Kurniawan, T. D., Nora, E., \& Narmaditya, S. B. (2020). Does Talent Management Affect Employee Performance? The Moderating Role of Work Engagement. Journal of Asian Finance, Economics and Business, 7(7), 335-341. https://doi. org/10.13106/jafeb.2020.vol7.no7.335

Statt, D. (2004). The Routledge Dictionary of Business Management ( $3^{\text {rd }}$ ed.). New York, NY: Routledge.

Susi, S., \& Jawaharrani, K. (2011). Work-Life Balance: The key driver of employee engagement. Asian Journal of Management Research, 2(1), 474-483.

Tennakoon, W., \& Lasanthika, W. (2018) Religiosity and engagement: Clarifying the relationship International Journal of Commerce and Management Research, 4(1), 52-57.

Tranfield, D., Denyer, D., \& Smart, P. (2003). Towards a methodology for developing evidence-informed management knowledge by means of systematic review. British Journal of Management, 14(3), 207-222.

Vitell, S. J. (2009). The role of religiosity in business and consumer ethics: A review of the literature. Journal of Business Ethics, 90(2), 155-167.

Vitell, S. J., Bing, M. N., Davison, H. K., Ammeter, A. P., Garner, B. L., \& Novicevic, M. M. (2009). Religiosity and moral identity: The mediating role of self-control. Journal of Business Ethics, 88(4), 601-613.

Vitell, S. J., Paolillo, J. G. P., \& Singh, J. J. (2005). Religiosity and consumer ethics. Journal of Business Ethics, 57(2), 175-181.

Whittington, J. L., Maellaro, R., \& Galpin, T. (2011). Redefining success: The foundation for creating work-life balance. In: S. Kaiser, M. Ringlstetter, D. R. Eikhof, \& M. P. E. Cunha (Eds.), Creating a balance? International perspectives on the work-life balance integration of professionals (pp. 3-26). 